Plant Sciences Research 11 (1): 1-7, 2019

ISSN: 1995-476X

(C) Medwell Journals, 2019

\title{
Phenological Traits of Common Bean (Phaseolus vulgaris L., Fabaceae) Landraces
}

\author{
${ }^{1}$ Tura Bareke, ${ }^{2}$ Zemede Asfaw and ${ }^{3}$ Berhanu Amssalu \\ ${ }^{1}$ Holeta Bee Research Center, Bee Forage and Pollination Ecology Research Team, \\ Oromia Agricultural Research Institute, Ethiopia \\ ${ }^{2}$ Department of Plant Biology and Biodiversity Management, \\ College of Natural and Computational Sciences, Addis Ababa University, Addis Ababa, Ethiopia \\ ${ }^{3}$ Melkassa Agricultural Research Center, National Pulse, \\ Ethiopian Institute of Agricultural Research, \\ Oil and Fiber Crops Research Program, Ethiopia
}

\begin{abstract}
The study was undertaken to identify the variation of phenological traits among landraces of common bean at field conditions of rift valley of Ethiopia. Twenty four common bean landraces from different geographical areas and agroecological zones were grown in three replications. Five phenological traits were collected using IBPGR protocol. The results of the study revealed that the average fresh pod and seed maturity time of zale wehy were significantly higher $(\mathrm{p}<0.05)$ than other landraces. Date of flowering was positively correlated $(\mathrm{p}<0.05)$ with fresh pod maturity $(\mathrm{r}=0.42)$ and dry seed maturity time $(\mathrm{r}=0.5)$. The highest diversity (3.17) was found in days to $50 \%$ flowering, fresh pod maturity time and dry seed maturity time among landraces while the lowest diversity was found in flowering length. This indicates that there is big variation among landraces in terms of days to $50 \%$ flowering, fresh pod maturity time and dry seed maturity time; while flowering length is almost similar for all landraces. Abbajolle, dima tikka, gardoy bushay and dobole took significantly shorter times $(p<0.05)$ to seed maturity. Early flowering and maturing of these landraces may give them comparative advantages to escape terminal drought that frequently occur in semi-arid areas. Therefore, crop breeders could give emphasis to these landraces to monitor and use for future production and for other purposes.
\end{abstract}

Key words: Maturity, common bean, landraces, pod, seed, traits

\section{INTRODUCTION}

Landraces are dynamic populations of cultivated plants with historical origin, distinct identity and lack formal crop improvement as well as often being genetically diverse, locally adapted and associated with traditional farming systems (Casanas et al., 2017; Bertoldo et al., 2014; Villa et al., 2005). They have particular characteristics (early or late maturing), a reputation for adaptation to local climatic conditions and cultural practices and resistance or tolerance to diseases, pests and various a biotic stresses (Newton et al., 2010; Harlan, 1992). Major advantages of landraces are adaptation to their specific agro-systems and low input requirements and factors also operate in traditional agricultural practices. It provides high yield stability and intermediate average yields under a low input agricultural system (Zemen, 1998). The genetic diversity of landraces is very important for global biodiversity conservation for future world production (Wood and Lenne, 1997).
Common bean (Phaseolus vulgaris L.) is the most widely grown and consumed grain legume in the world and plays an especially significant role in human diet (Khoury et al., 2014). Common bean is very important for food security in Latin America and East and Southern Africa. It is rich in protein and essential vitamins and minerals (Beebe, 2012). For the low-income segment of the population, common bean plays a strategic role in alleviating the rampant problems of malnutrition (Svetleva et al., 2006). It is cultivated in a wide range of production systems, representing different climates, soils, cultivars and levels of technology. Growth and development of crops are strongly dependent on temperature (Kar and Uzun, 2000) and soil nutrients (Araujo et al., 2000).

Ethiopia is a country in which the legume family holds the highest number of species (about 10\% of the flora) containing many leguminous crop species known for rich inter and intraspecific diversity (Bareke et al., 2018). In Ethiopia, common bean is produced in almost all the regional states but with varying amount of

Corresponding Author: Tura Bareke, Holeta Bee Research Center, Oromia Agricultural Research Institute, Bee Forage and Pollination Ecology Research Team, Ethiopia 
production. The $75 \%$ of the total national production of common bean comes from Oromia and the Southern Nations, Nationalities and Peoples Region (SNNPR) and $25 \%$ from Afar, Amhara, Tigray, Somali, Gambella and Benishangul-Gumuz Regions (Katungi et al., 2009; CSA, 2011).

Common bean contains high protein content especially in lysine which is relatively deficient in maize, cassava, rice and other cereals, making it a good complement to these staples in the diet. It promotes heart health because it is rich source of potassium, dietary fiber including cholesterol-binding soluble fiber, contain no sodium and cholesterol, fat free food, heart-healthy vegetation protein, excellent source of folic acid, consumption helps with weight management, people with diabetes who consume cooked, common bean had a lower risk of heart disease and pair well with other heart health promoting foods like fish and extra virgin olive oil (Messina, 2014).

In Southern and Eastern Ethiopia common bean is grown between 1500-2500 $\mathrm{m}$ a.s.1 (Bareke et al., 2018). Thus, determining the maturity period of common bean landraces is an important preliminary step to select the best that can survive climate changes for further use and suggest strategies in maintaining and valuing diversity (Jarvis et al., 1999). This is used to estimate the existing diversity and suggest appropriate plans for the management and improvement of genetic resources in the future (Schut et al., 1997). Improved high yielding short duration varieties along with proper management practices are very important to improve the resilience of farming in the drought prone areas. Changes in climate also have a variety of management implications that is early sowing and of cultivars that can escape drought through early flowering and early maturity and it is better option for risk reduction.

Ethiopia has a considerable amount of comm on bean genetic diversity which needs renewed conservation efforts for the region (Bareke et al., 2018; Asfaw et al., 2009). For conservation and use, identification of maturity time of common bean landraces is very important. Therefore, the main purpose of this study was to identify the variation of phenological traits among the common bean landraces from germplasm collection.

\section{MATERIALS AND METHODS}

The study was conducted in Melkassa Agricultural Research Center, Adama District, Ethiopia (Fig. 1).

Plant materials: The materials used in this study were 24 common bean (Phaseolus vulgaris L.) landraces (Table 1). The landraces were collected from different geographic origin of Oromia and Southern Nations, Nationalities and Peoples (SNNP) regions of Ethiopia (Bareke et al., 2018). Sowing took place at the experimental field of the Melkassa Agricultural Research Center using irrigation. The experiment was arranged in a randomized complete block design with three replications for one season, on an experimental plot of $1.2 \mathrm{~m}^{2}$ with 20 plants were grown per plot. To keep proper spacing and avoid competition for nutrients, space

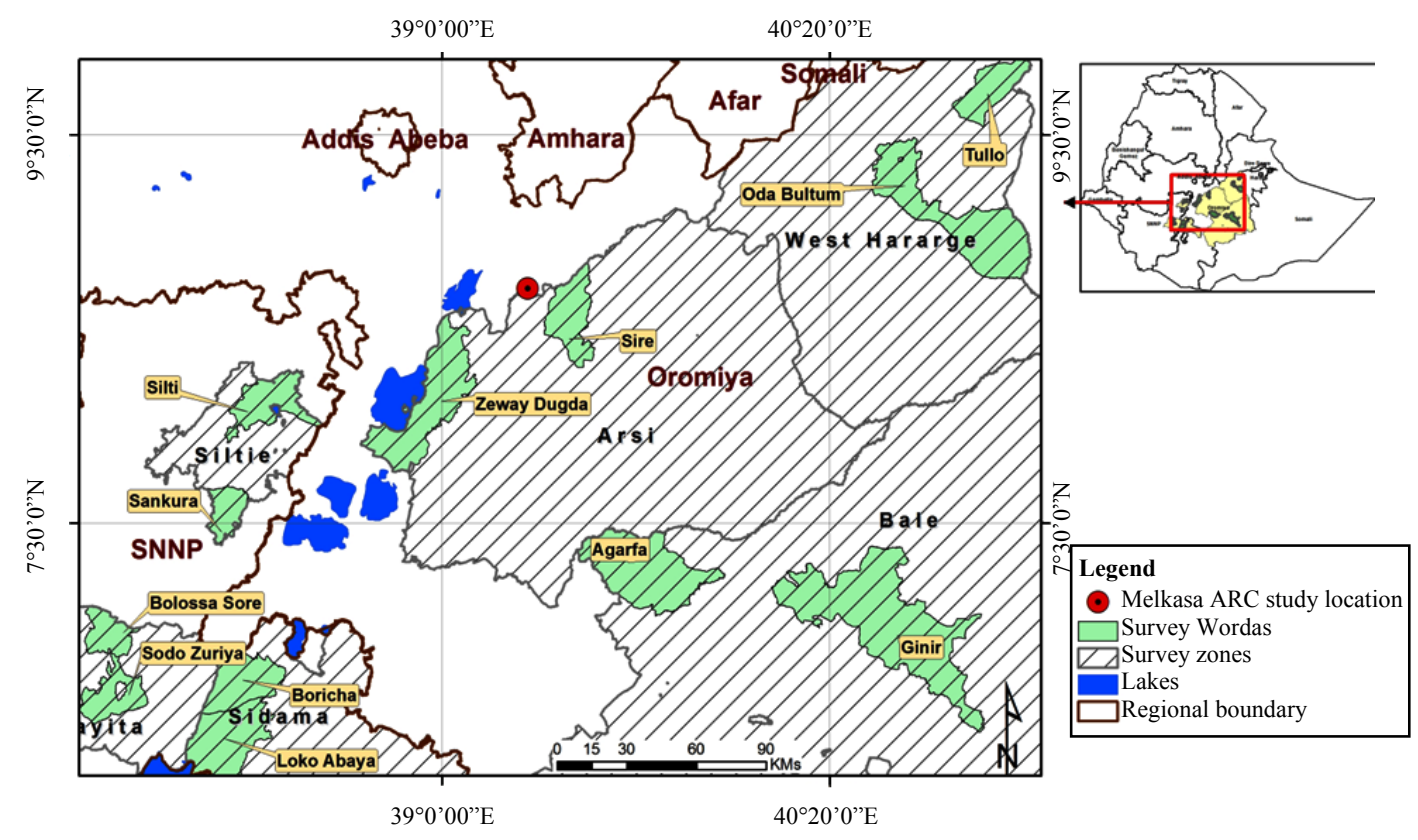

Fig. 1: Map of Ethiopia showing the sites of common bean seed collection and the experimental site 
Plant Sci. Res., 11 (1): 1-7, 2019

Table 1: List of common bean landraces included, along with collection and accession numbers, coordinates and region of collection sites

\begin{tabular}{|c|c|c|c|c|c|}
\hline Accession No. & Latitude (N) (dd mm ss) & Longitude (E) (dd mm ss) & Altitude (m a.s.l) & Region & Landrace name \\
\hline TBK109 & $08^{\circ} 19^{\prime} 02.4^{\prime \prime}$ & $039^{\circ} 28^{\prime} 48.3^{\prime \prime}$ & 1745 & Oromia & Dima Tikka \\
\hline TBK117 & $08^{\circ} 03^{\prime} 19.3^{\prime \prime}$ & $038^{\circ} 57^{\prime} 39.4^{\prime \prime}$ & 1660 & Oromia & Abbajolle \\
\hline TBK128 & $08^{\circ} 06^{\prime} 05.4^{\prime \prime}$ & $038^{\circ} 58^{\prime} 46.8^{\prime \prime}$ & 1673 & Oromia & Dalacha Dima \\
\hline TBK130 & $08^{\circ} 02^{\prime} 51.6^{\prime \prime}$ & $039^{\circ} 00^{\prime} 35.9^{\prime \prime}$ & 1682 & Oromia & Bora \\
\hline TBK 058 & $07^{\circ} 12^{\prime} 35.6^{\prime \prime}$ & $040^{\circ} 33^{\prime} 25.1^{\prime \prime}$ & 2143 & Oromia & Bar Bolokke \\
\hline TBK062 & $07^{\circ} 09^{\prime} 53.3^{\prime \prime}$ & $040^{\circ} 38^{\prime} 53.7^{\prime \prime}$ & 1995 & Oromia & Mishigani \\
\hline TBK138 & $07^{\circ} 19^{\prime} 43.1^{\prime \prime}$ & $039^{\circ} 51^{\prime} 36.3^{\prime \prime}$ & 2401 & Oromia & Zale Wehy \\
\hline TBK141 & $07^{\circ} 19^{\prime} 43.1^{\prime \prime}$ & $039^{\circ} 51^{\prime} 36.3^{\prime \prime}$ & 2401 & Oromia & Dobole \\
\hline TBK010 & $08^{\circ} 52^{\prime} 22.6^{\prime \prime}$ & $040^{\circ} 41^{\prime} 02.0^{\prime \prime}$ & 1809 & Oromia & Bora Chulukkisa \\
\hline TBK018 & $08^{\circ} 53^{\prime} 35.3^{\prime \prime}$ & $040^{\circ} 43^{\prime} 20.1^{\prime \prime}$ & 1760 & Oromia & Dima \\
\hline TBK038 & $09^{\circ} 12^{\prime} 52.5^{\prime \prime}$ & $041^{\circ} 06^{\prime} 12.7^{\prime \prime}$ & 2180 & Oromia & Adi Battee \\
\hline TBK040 & $09^{\circ} 10^{\prime} 43.2^{\prime \prime}$ & $041^{\circ} 03^{\prime} 22.2^{\prime \prime}$ & 2180 & Oromia & Kalibushay \\
\hline TBK043 & $06^{\circ} 57^{\prime} 37.3^{\prime \prime}$ & $038^{\circ} 20^{\prime} 08.9^{\prime \prime}$ & 1856 & SNNP & Yumbube \\
\hline TBK152 & $06^{\circ} 41^{\prime} 54.4^{\prime \prime}$ & $038^{\circ} 15^{\prime} 56.1^{\prime \prime}$ & 1686 & SNNP & Logoma Wajjo \\
\hline TBK051 & $06^{\circ} 57^{\prime} 37.2^{\prime \prime}$ & $038^{\circ} 20^{\prime} 08.8^{\prime \prime}$ & 1860 & SNNP & Adi Tikko \\
\hline TBK048 & $06^{\circ} 57^{\prime} 37.2^{\prime \prime}$ & $038^{\circ} 20^{\prime} 08.8^{\prime \prime}$ & 1860 & SNNP & Dume \\
\hline TBK080 & $07^{\circ} 59^{\prime} 59.7^{\prime \prime}$ & $038^{\circ} 18^{\prime} 424^{\prime \prime}$ & 2190 & SNNP & Zoolokoma \\
\hline TBK 090 & $08^{\circ} 03^{\prime} 56.1^{\prime \prime}$ & $038^{\circ} 21^{\prime} 47.5^{\prime \prime}$ & 2173 & SNNP & Arusicho \\
\hline TBK091 & $08^{\circ} 03^{\prime} 56.1^{\prime \prime}$ & $038^{\circ} 21^{\prime} 47.5^{\prime \prime}$ & 2173 & SNNP & Logoma Dume \\
\hline TBK093 & $08^{\circ} 03^{\prime} 56.1^{\prime \prime}$ & $038^{\circ} 21^{\prime} 47.5^{\prime \prime}$ & 2173 & SNNP & Zoolokomakareta \\
\hline TBK070 & $06^{\circ} 46^{\prime} 10.8^{\prime \prime}$ & $037^{\circ} 45^{\prime} 04.6^{\prime \prime}$ & 1872 & SNNP & Dima Burre \\
\hline TBK073 & $06^{\circ} 41^{\prime} 56.4^{\prime \prime}$ & $037^{\circ} 45^{\prime} 44.1^{\prime \prime}$ & 1995 & SNNP & Gardoy Bushay \\
\hline TBK067 & $07^{\circ} 06^{\prime} 25.7^{\prime \prime}$ & $037^{\circ} 43^{\prime} 04.1^{\prime \prime}$ & 1719 & SNNP & Walensu \\
\hline TBK068 & $06^{\circ} 46^{\prime} 11.8^{\prime \prime}$ & $037^{\circ} 45^{\prime} 03.3^{\prime \prime}$ & 1859 & SNNP & Gumaray \\
\hline
\end{tabular}

Bareke et al. (2016)

required is $10 \mathrm{~cm}$ among plants and $60 \mathrm{~cm}$ between rows (IBPGR, 1982). Space required for water movement was $1 \mathrm{~m}$ and space required between replications was $1.5 \mathrm{~m}$. Fertilizer rates used were the homogenized mix of $120 \mathrm{~kg}$ DAP and $60 \mathrm{~kg}$ urea per hectare.

Five descriptors of common bean were evaluated for each landrace following the recommended procedure (IBPGR, 1982). Data on Germination Date/emergence (GD) (number of days from sowing until $50 \%$ of the seedlings have emerged); Days to Flowering (DF) (number of days from sowing until $50 \%$ of the plants has at least, one opened flower); Flowering Period (FP) (number of days from the beginning of flowering until $100 \%$ plants had flower abscission); Fresh Pod Maturity (FPM) (numbers of days from sowing until $50 \%$ of the plants have at least one pod with the optimal stage for fresh consumption) and dry seed maturity (number of days from sowing until $90 \%$ of the plants have reached the physiological maturity) were taken following the standard protocol (IBPGR, 1982).

Data analysis: One-way ANOVA was used to analysis the significant differences among landraces on the basis of their phenological traits.

Shannon-Wiener Index $(\mathrm{H})$ was used to estimate phenological variation among landraces (Shannon and Weaver, 1949), according to the following equation:

$$
\text { Shannon index }\left(\mathrm{H}^{\prime}\right)=-\sum_{\mathrm{i}=1}^{\mathrm{s}} \mathrm{Pi} * \ln \mathrm{Pi}
$$

Where:

$\mathrm{H}^{\prime}$ : Shannon-Wiener diversity index

$\mathrm{s}$ : The number of landraces
$P_{i}$ : The proportion of individuals measurement of the $i^{\text {th }}$ phenological traits of landraces

ln : The natural logarithm

$\Sigma$ : Sum from landraces 1 to landraces $\mathrm{S}$

Evenness (E) was also calculated separately as a measure of the ratio of the observed diversity to the maximum diversity. It is defined by the function $\mathrm{E}=\mathrm{H}^{\prime} / \mathrm{ln}$ $\mathrm{s}$ where $\mathrm{H}^{\prime}$ is Shannon index and $\mathrm{s}$ refers to the number of landraces recorded.

\section{RESULTS AND DISCUSSION}

The mean germination days of zoolokoma and zoolokoma kareta were significantly higher $(p<0.05)$ than other landraces. These two landraces need more time to germinate whereas walensu was significantly lower $(p<0.05)$ and it stays in the soil for a few days to germinate as compared to the other landraces (Table 2). The same table shows that the days to flowering of common bean landraces have no significant differences ( $p<0.05$ ) amongst them.

The flowering length of dima tikka from the beginning of flowering until $100 \%$ plants had flower abscission was significantly higher $(\mathrm{p}<0.05)$ than the other landraces. Abbajolle and adi batte had significantly $(p<0.05)$ shorter flowering period than other landraces. The mean flowering periods for all landraces ranged between $4.7-10.7$ days (Table 2).

The mean fresh pod maturity time of zale wehy was significantly different $(p<0.05)$ from other landraces with the highest mean days followed by gumaray whereas abbajolle took the shortest time to reach fresh pod maturity (Table 3 ). Similarly, the mean dry seed maturity 
Plant Sci. Res., 11 (1): 1-7, 2019

Table 2: Mean $50 \%$ Germination Date (GD), Days to $50 \%$ Flowering (DF) and Flowering Period (FP) \pm Standard Deviation (SD) of common bean landraces

\begin{tabular}{llll}
\hline Landraces & GD \pm SD & DF \pm SD & FP \pm SD \\
\hline Abbajolle & $14.3 \pm 3.0 \mathrm{abcd}$ & $56 \pm 1.7 \mathrm{a}$ & $4.7 \pm 0.6 \mathrm{c}$ \\
Adi battee & $12.7 \pm 3.0 \mathrm{abcd}$ & $57 \pm 2.6 \mathrm{a}$ & $5 \pm 1 \mathrm{bc}$ \\
Adi tikko & $11.3 \pm 1.2 \mathrm{bcd}$ & $55 \pm 0.6 \mathrm{a}$ & $8.7 \pm 1.5 \mathrm{abc}$ \\
Arusicho & $13 \pm 2.6 \mathrm{abcd}$ & $57 \pm 4.2 \mathrm{a}$ & $5.3 \pm 2.3 \mathrm{abc}$ \\
Bar bolokke & $12.3 \pm 0.6 \mathrm{abcd}$ & $54 \pm 2 \mathrm{a}$ & $6.3 \pm 2 \mathrm{abc}$ \\
Bora & $15 \pm 2.6 \mathrm{abc}$ & $57 \pm 3.6 \mathrm{a}$ & $7.3 \pm 2.8 \mathrm{abc}$ \\
Bora chulukkisa & $14.7 \pm 2.5 \mathrm{abc}$ & $55 \pm 2.6 \mathrm{a}$ & $10.3 \pm 4 \mathrm{ab}$ \\
Dalacha dima & $12.3 \pm 1.5 \mathrm{abcd}$ & $55 \pm 1 \mathrm{a}$ & $7.7 \pm 2.5 \mathrm{abc}$ \\
Dima & $13.3 \pm 3.2 \mathrm{abcd}$ & $56 \pm 3.2 \mathrm{a}$ & $7.7 \pm 4.6 \mathrm{abc}$ \\
Dima burre & $12.7 \pm 1.2 \mathrm{abcd}$ & $55 \pm 1.5 \mathrm{a}$ & $8.3 \pm 3.5 \mathrm{abc}$ \\
Dima tikka & $14.7 \pm 3.5 \mathrm{abc}$ & $55 \pm 3 \mathrm{a}$ & $10.7 \pm 3.5 \mathrm{a}$ \\
Dobole & $16 \pm 3.6 \mathrm{ab}$ & $57 \pm 2.6 \mathrm{a}$ & $6.7 \pm 0.6 \mathrm{abc}$ \\
Dume & $13.3 \pm 1.5 \mathrm{abcd}$ & $56 \pm 1 \mathrm{a}$ & $8.3 \pm 1.2 \mathrm{abc}$ \\
Gardoy bushay & $12 \pm 2 \mathrm{abcd}$ & $55 \pm 2.5 \mathrm{a}$ & $7.0 \pm 1 \mathrm{abc}$ \\
Gumaray & $11 \pm 1.7 \mathrm{~cd}$ & $56 \pm 2.6 \mathrm{a}$ & $5.7 \pm 2.8 \mathrm{abc}$ \\
Kalibushay & $14 \pm 2.6 \mathrm{abcd}$ & $56 \pm 1 \mathrm{a}$ & $6.7 \pm 2.3 \mathrm{abc}$ \\
Logoma dume & $14.3 \pm 2.5 \mathrm{abcd}$ & $57 \pm 3 \mathrm{a}$ & $7 \pm 1 \mathrm{abc}$ \\
Logoma waijo & $12 \pm 2.6 \mathrm{abcd}$ & $56 \pm 0.1 \mathrm{a}$ & $6.0 \pm 0.1 \mathrm{abc}$ \\
Mishigani & $11.7 \pm 2.0 \mathrm{abcd}$ & $56 \pm 2 \mathrm{a}$ & $6.7 \pm 0.6 \mathrm{abc}$ \\
Walensu & $9.7 \pm 1.5 \mathrm{~d}$ & $55 \pm 2.5 \mathrm{a}$ & $6.3 \pm 1.2 \mathrm{abc}$ \\
Yumbube & $13.7 \pm 2.8 \mathrm{abcd}$ & $56 \pm 1.5 \mathrm{a}$ & $5.7 \pm 0.6 \mathrm{abc}$ \\
Zale wehy & $15.7 \pm 2 \mathrm{abc}$ & $58 \pm 1.5 \mathrm{a}$ & $7.7 \pm 6.3 \mathrm{abc}$ \\
Zoolokoma & $16.5 \pm 2.1 \mathrm{a}$ & $58 \pm 2.8 \mathrm{a}$ & $8.0 \pm 1.4 \mathrm{abc}$ \\
Zoolokoma kareta & $16.3 \pm 2.8 \mathrm{a}$ & $55 \pm 2.3 \mathrm{a}$ & $9.0 \pm 5.5 \mathrm{abc}$ \\
Different letters show significant differences &
\end{tabular}

Table 3: Mean Fresh Pod Maturity Time (FPMT) and 90\% Dry Seed Maturity Time (DSMT) \pm StandardDeviation (SD) of common bean landraces

\begin{tabular}{lll}
\hline Landraces & FPMT \pm SD & DSMT \pm SD \\
\hline Abbajolle & $74 \pm 1 \mathrm{k}$ & $84.3 \pm 1.5 \mathrm{j}$ \\
Adi battee & $81.3 \pm 1.5 \mathrm{efghi}$ & $92.3 \pm 2.5 \mathrm{de}$ \\
Adi tikko & $80 \pm 3$ fghij & $88.3 \pm 1.5 \mathrm{fghi}$ \\
Arusicho & $82.7 \pm 3$ def & $92 \pm 2 \mathrm{def}$ \\
Bar bolokke & $82.7 \pm 0.6 \mathrm{def}$ & $94.3 \pm 2.3 \mathrm{~cd}$ \\
Bora & $86.3 \pm 1.5 \mathrm{bc}$ & $98 \pm 2 \mathrm{c}$ \\
Bora chulukkisa & $77.3 \pm 1.5 \mathrm{j}$ & $89.3 \pm 1.5 \mathrm{efgh}$ \\
Dalacha dima & $81.7 \pm 1.5 \mathrm{efgh}$ & $88 \pm 3$ ghij \\
Dima & $82 \pm 1$ efg & $90.7 \pm 1.2 \mathrm{defg}$ \\
Dima burre & $80.7 \pm 0.6$ efghij & $88.3 \pm 1.5 \mathrm{fghi}$ \\
Dima tikka & $79 \pm 1 \mathrm{hgi}$ & $85.3 \pm 4.2 \mathrm{ij}$ \\
Dobole & $77.3 \pm 3.5 \mathrm{j}$ & $86 \pm 1.7 \mathrm{hij}$ \\
Dume & $78 \pm 1 \mathrm{ij}$ & $87.7 \pm 2 \mathrm{ghij}$ \\
Gardoy bushay & $77.7 \pm 2 \mathrm{j}$ & $84.3 \pm 0.6 \mathrm{j}$ \\
Gumaray & $88.3 \pm 1.5 \mathrm{~b}$ & $104 \pm 1 \mathrm{~b}$ \\
Kalibushay & $83.7 \pm 1.2 \mathrm{cde}$ & $92.7 \pm 1.5 \mathrm{de}$ \\
Logoma dume & $80.7 \pm 2$ efghij & $94.3 \pm 2 \mathrm{~cd}$ \\
Logoma wajjo & $82.7 \pm 0.6 \mathrm{def}$ & $94.3 \pm 2.5 \mathrm{~cd}$ \\
Mishigani & $85.3 \pm 1.5 \mathrm{bcd}$ & $97.7 \pm 0.6 \mathrm{c}$ \\
Walensu & $78.3 \pm 2$ hij & $88 \pm 2.6 \mathrm{ghij}$ \\
Yumbube & $85.3 \pm 1.5 \mathrm{bcd}$ & $93.3 \pm 1.5 \mathrm{c}$ \\
Zale wehy & $93.3 \pm 1.5 \mathrm{a}$ & $112 \pm 2.6 \mathrm{a}$ \\
Zoolokoma & $80.5 \pm 0.7$ efghij & $85.5 \pm 0.7 \mathrm{hij}$ \\
Zoolokoma kareta & $80.7 \pm 1.2 \mathrm{efghij}$ & $87 \pm 1$ ghij \\
\hline Different letters show significant differences &
\end{tabular}

time of zale wehy was significantly higher $(p<0.05)$ than the other landraces. It took the longest time to mature until $90 \%$ of the plants have reached the physiological maturity followed by gumaray while abbajolle and gardoy bushay were significantly $(\mathrm{p}<0.05)$ lower than other landraces. Dry seed maturity times of these two landraces were the shortest of all landraces (Table 3).
Table 4: Correlations among all examined variables in common bean landraces at adama, Ethiopia

Pearson correlation coefficients, $\mathrm{N}=24$; Prob $>|\mathrm{r}|$ under $\mathrm{H} 0$ : Rho $=0$

\begin{tabular}{llllll} 
Traits & GD & DF & FP & FPMT & DSMT \\
\hline GD & 1 & 0.34203 & $0.40584^{*}$ & -0.03264 & -0.05997 \\
DF & 0.34203 & 1 & -0.33166 & $0.41558^{*}$ & $0.49785^{*}$ \\
FP & $0.40584^{*}$ & -0.33166 & 1 & -0.17415 & -0.22956 \\
FPMT & -0.03264 & $0.41558^{*}$ & -0.17415 & 1 & $0.9188^{* * * * *}$ \\
DSMT & -0.05997 & $0.49785^{*}$ & -0.22956 & $0.9188^{* * * * *}$ & 1 \\
\hline *Significant at $\mathrm{p}<0.05$, * $^{* * *}$ Significt & $\mathrm{p}<0.01, * * *$ Significant
\end{tabular}

*Significant at $\mathrm{p}<0.05$, ***:Significant at $\mathrm{p}<0.01$, *****Significant at $<0.001$

Table 5: Shannon diversity index $\left(\mathrm{H}^{\prime}\right)$, maximum diversity $\left(\mathrm{H}_{\max }\right)$ and Evenness ( $E$ ) for traits in 24 common bean landraces evaluated during 2016 at the Melkassa Agricultural Research Center, Adama, Ethiopia

\begin{tabular}{lccc}
\hline Traits (Days) & $\begin{array}{c}\text { Shannon diversity } \\
\text { index }\left(\mathrm{H}^{\prime}\right)\end{array}$ & $\mathrm{H}_{\text {mar }}$ & Evenness (E) \\
\hline Germination date & 2.40 & 2.79 & 0.86 \\
Days to 50\% flowering & 3.17 & 4.07 & 0.78 \\
Flowering period/length) & 1.50 & 2.37 & 0.63 \\
Fresh pod maturity time & 3.17 & 4.54 & 0.70 \\
Days to dry seed maturity time & 3.17 & 4.64 & 0.68 \\
\hline
\end{tabular}

Based on five phenological traits those 24 landraces were classified into 5 major categories (Figure 2). Accordingly, group I: include 1. Abbajolle, 10. Dima tikka, 12. Dobole, 14. Gardoy bushay and 24. Zoolokoma; group II: 7. Bora chulukkisa, 8. Dalacha dima, 9. Dima burre, 13. Dume, 20. Walensu and 23. Zoolokoma kareta; group III: 2. Adi battee, 3. Adi tikko, 4. Arusicho, 5. Bar boloke, 11. Dima, 16. Kalibushay, 17. Logoma wajjo, 18. Logoma DUME and 21. Yumbube; group IV: 22. Zale wehy; group V: 6. Bora, 15. Gumaray and 19. Mishigani.

As shown in Table 4, date of flowering was positively correlated $(\mathrm{p}<0.05)$ with fresh pod maturity $(r=0.42)$ and dry seed maturity time $(r=0.5)$. Germination date has direct relationship $(\mathrm{r}=0.4)$ with flowering period at $p<0.05$. Fresh pod maturity time was positively correlated $(\mathrm{p}<0.001)$ with dry seed maturity time $(r=0.92)$. It was also positively correlated $(p<0.05)$ with date of flowering.

The highest diversity (3.17) was found in days to $50 \%$ flowering, fresh pod maturity time (day) and dry seed maturity time among landraces while the lowest diversity was found in flowering length (Table 5). This indicates that there is big variation among landraces in terms of days to $50 \%$ flowering, fresh pod maturity time (day) and dry seed maturity time. On the other hand, germination date is almost similar among the landraces.

Determining of maturity time of local variety is very important to facilitate breeding efforts. Air temperature and rainfall pattern greatly affect the growth and development of common bean plants as well as its productivity (Mouhouche et al., 1998). In addition to this, drought and heat stress strongly influence common bean development (Kazai et al., 2019). Development of drought adapted common bean varieties is an important strategy to minimize crop failure and increase food 


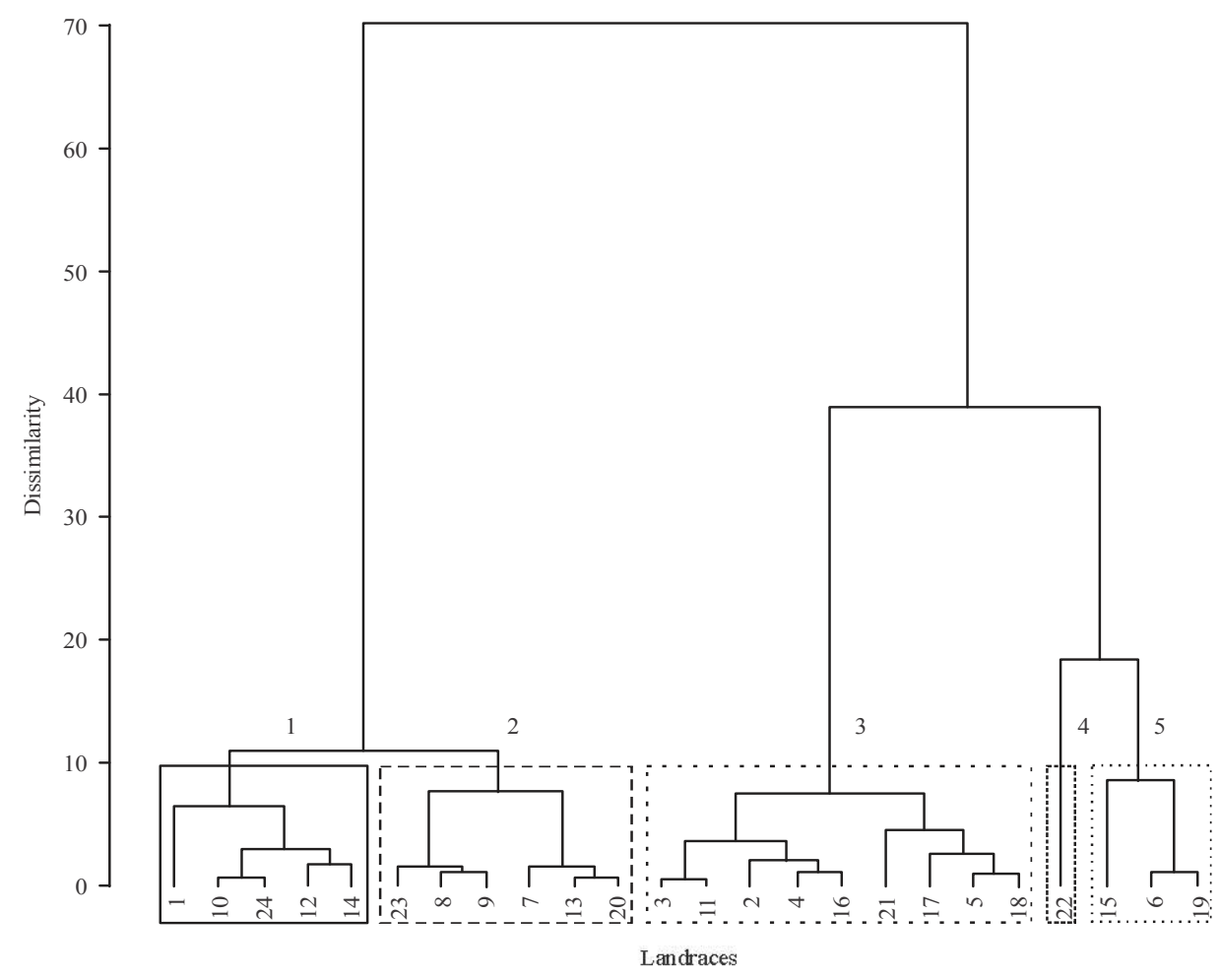

Fig. 2: Agglomerative hierarchical classification of landraces based on phenological traits; Note: 1. Abbajolle, 2. Bdi battee, 3. Adi tikko, 4. Arusicho, 5. Bar boloke, 6. Bora, 7. Bora chulukkisa, 8. Dalacha dima, 9. Dima burre, 10. Dima tikka, 11. Dima, 12. Dobole, 13. Dume, 14. Gardoy bushay, 15. Gumaray, 16. Kalibushay, 17. Logoma wajjo, 18. Logoma dume, 19. Mishigani, 20. Walensu, 21. Yumbube, 22. Zale wehy, 23. Zoolokoma kareta, 24. Zoolokoma

security in the face of climate change. Identification of key plant traits and mechanisms that contribute to improved drought adaptation can increase the efficiency of breeding programs through the selection of superior genotypes (Kargiotidou et al., 2019).

The mean germination days for all landraces ranged between 9.7-16.5 days until $50 \%$ of the seedlings have emerged from the soil in the field. However, it was explained (Wallace et al., 1991) that in the field, common bean landraces have completed initial germination days within 7-8 days after planting. According to sources (McCormack, 2004), if soil temperatures are below $18^{\circ} \mathrm{C}$, days for seedling emergence of common bean may take 2 weeks or more. Common bean requires $18-25^{\circ} \mathrm{C}$ for its proper growth and development (Labuda and Brodaczewska, 2007). In field cultivation, the sowing should be made when the risk of frost is low. However, a study conducted by Suzuki et al. (2001) revealed that common bean plants are characterized by susceptibility to high temperatures during their generative growth. The maximum temperature during flowering should not exceed $30^{\circ} \mathrm{C}$. High temperatures during the flowering stage lead to abscission of flowers and a low pod set, resulting in yield loss.
The mean days to $50 \%$ flowering for all landraces ranged between 54-58 days. Days to flowering also vary among common bean landraces which generally ranges from 35-75 days among common bean landraces in Mexico (Stoilova et al., 2013). On the other hand, the variation in days to flowering ranged from 26-51 days among landraces from Uganda (Okii et al., 2014). The days to flowering and the length of the flowering period of common bean varied depending on the types of landraces and environmental conditions (Wallace et al., 1991).

The time taken to fresh pod maturity of these landraces was found between 2-3 months. The study conducted by Balkaya and Ergun (2007) on common bean genotypes in Turkey also indicted that the time from seed sowing to harvest varied between 71 and 143 days for fresh pod maturity time. Another study (IbarraPerez et al., 1999) revealed that poorer pod setting on common bean may occur in the absence of pollinating insects which was proven for some dwarf cultivars. Flower and pod falling is a common phenomenon which may result from insufficient pollination of the flowers. At higher soil humidity and with shortened daylight hours, plants produce many flowers but only 
$7-12 \%$ of them set pods (Helena and Anna, 2007). With lower soil moisture content and longer daylight hours, plants form a lower number of flowers but $17-24 \%$ of them produce pods and therefore, the yield is higher (Prusinski and Borowska, 2002)

The time taken to dry seed maturity time of all landraces was found between 3-4 months. Seed has to undergo a period of maturation drying before harvesting and threshing are possible without causing physical damage to the seed. Maximum dry seed weight is attained at physiological maturity and it is used to improve viability and vigour of seed (Krony and Egli, 1997). The seed maturity time of common bean landraces varied widely from 50 to more than 250 days (SandovalAvila et al., 1994). It depends on the variety, photoperiod response and temperature conditions. Day temperatures below $20^{\circ} \mathrm{C}$ will delay maturity and cause empty mature pods to develop.

Abbajolle, dima tikka, gardoy bushay and dobole took significantly shorter times for dry seed maturity compared to other landraces. Early flowering and maturing of these landraces may help them to escape terminal drought frequently occurring in the semi-arid areas.

Many researchers (Beebe et al., 2011); RamirezVillegas et al., 2013) have suggested that extreme heat and drought will cause widespread losses in yields and suitability of common beans. Therefore such landraces are more economical as they take less time to grow and it is the most important and feasible climate change adaptation strategy for crop production and productivity.

\section{CONCLUSION}

Phenological variation observed among local varieties or landraces showed that there is enough scope for selection of suitable landraces for various production systems. The variability observed in $50 \%$ germination date, days to $50 \%$ flowering, flowering period or length, fresh pod maturity time and days to dry seed maturity time traits could be utilized in variety improvement programs. Abbajolle, dima tikka, gardoy bushay and dobole are significantly fast maturing varieties compared to the other landraces. Therefore, crop breeders could give priority and emphasis to these landraces to monitor and use for the future production and for other purposes.

\section{ACKNOWLEDGEMENTS}

We would like to thank the Holeta Bee Research Center and Oromia Agricultural Research Institute for providing required facilities and logistics. Our sincere thanks are also to the Melkassa Agricultural Research Center forallocating land for the study. Our sincere thanks extended to Mr Belete Dagne and Sirak Teshome, for their inspiration and support in the implementation and follow-up of the research from land preparation up to the end of the study.

\section{REFERENCES}

Araujo, A.P., M.G. Teixeira and D.L. Almeida, 2000. Growth and yield of common bean cultivars at two soil phosphorous levels under biological nitrogen fixation. Pesq. Agropec. Bras., 35: 809-817.

Asfaw, A., M.W. Blair and C. Almekinders, 2009. Genetic diversity and population structure of common bean (Phaseolus vulgaris L.) landraces from the east African highlands. Theor. Applied Genet., 120: 1-12.

Balkaya, A. and A. Ergun, 2007. Determination of superior pinto bean (Phaseolus vulgaris L. var. Pinto) genotypes by selection under the Ecological conditions of Samsun province, Turkey. Turk. J. Agric. For., 31: 335-347.

Bareke, T., Z. Asfaw and Z. Woldu, 2018. Diversity of common bean (Phaseolus vulgaris L., fabaceae) landraces in South Eastern Ethiopia. Adv. Plants Agric. Res., 8: 449-457.

Bareke, T., Z. Asfaw, Z. Woldu, B.A. Medvecky and B. Amsalu, 2016. Landrace diversity of common bean (Phaseolus vulgaris L., Fabaceae) in parts of Oromia and SNNP Regions, Ethiopia. M.Sc. Thesis, Addis Ababa University, Addis Ababa, Ethiopia.

Beebe, S., 2012. Common Bean Breeding in the Tropics. In: Plant Breeding Reviews, Goldman, I. (Ed.). John Wiley \& Sons, Hoboken, New Jersey, USA., ISBN: 9781118345849, pp: 357-426.

Beebe, S., J. Ramirez, A. Jarvis, I.M. Rao, G. Mosquera, J.M. Bueno and M.W. Blair 2011. Genetic Improvement of Common Beans and the Challenges of Climate Change In: Crop Adaptation to Climate Change, Yadav, S.S., R. Redden, J.L. Hatfield, H. Lotze-Campen and A. Hall (Eds.). John Wiley \& Sons, Hoboken, New Jersey, USA., pp: 356-369.

Bertoldo, J.G., J.L.M. Coimbra, A.F. Guidolin, L.R.B.D. Andrade and R.O. Nodari, 2014. Agronomic potential of genebank landrace elite accessions for common bean genetic breeding. Sci. Agricola, 71: 120-125.

CSA., 2011. Agricultural sample survey: Report on area and production of major crops. Central Statistical Agency (CSA), Addis Ababa, Ethiopia.

Casanas, F., J. Simo, J. Casals and J. Prohens, 2017. Toward an evolved concept of landrace. Fron. Plant Sci., Vol. 8, No.145. 10.3389/fpls.2017.00145

Harlan, J.R., 1992. Crops and Man. 2nd Edn., American Society of Agronomy, Madison, Wisconsin, USA., ISBN: 9780891181071, Pages: 284. 
IBPGR., 1982. Phaseolus vulgar is descriptors. International Board for Plant Genetic Resources, Rome, Italy. https:/www.bioversityinternational.org/ fileadmin/migrated/uploads/tx_news/Phaseolus_v ulgaris_descriptors_160.pdf

Ibarra-Perez, F.J., D. Barnhart, B. Ehdaie, K.M. Knio and J.G. Waines, 1999. Effects of insect tripping on seed yield of common bean. Crop Sci., 39: 428-433.

Jarvis, D., M. Zhou, H. Klemick and B. Sthapit, 1999. In situ conservation on-farm. Proceedings of National Workshop on Conservation and Utiilization of Plant Genetic Resources, October 25-27, 1999, IPGR, Beijing, China, pp: 26-32.

Kar, H. and S. Uzun, 2000. The effect of different planting times on plant development and yield in broccoli. J. Agric. Fac. Ondokuz Mayıs Univ., 15: 53-61.

Kargiotidou, A., F. Papathanasiou, D. Baxevanos, D.N. Vlachostergios, S. Stefanou and I. Papadopoulos, 2019. Yield and Stability for agronomic and seed quality traits of common bean genotypes under Mediterranean conditions. Legume Res. Int. J., 42: 308-313.

Katungi, E., A. Farrow, J. Chianu, L. Sperling and $\mathrm{S}$. Beebe, 2009. Common bean in eastern and Southern Africa: A situation and outlook analysis. Int. Centre Trop. Agric., 61: 1-44.

Kazai, P., C. Noulas, E. Khah and D. Vlachostergios, 2019. Yield and seed quality parameters of common bean cultivars grown under water and heat stress field conditions. AIMS. Agric. Food, 4: 285-302.

Khoury, C.K., A.D. Bjorkman, H. Dempewolf, J. Ramirez-Villegas and L. Guarino et al., 2014. Increasing homogeneity in global food supplies and the implications for food security. Proc. National Acad. Sci., 111: 4001-4006.

Krony, D.M.T. and D.B. Egli, 1997. Accumulation of Seed Vigour During Development and Maturation. In: Basic and Applied Aspects of Seed Biology, Ellis, R.H., M. Black, A.J. Murdock and Hong T.D. (Eds.). Kulwer Academic, London, ISBN-13: 978-94-010-6410-1, pp: 369-384.

Labuda, H. and A. Brodaczewska, 2007. The influence of environmental factors on flowering of French bean [Phaseolus vulgaris L.]. Acta Agrobotanica, 60: $153-159$.

McCormack, J.H., 2004. Bean seed production: An organic seed production manual for seed growers in the mid-atlantic and Southern US. McCormack, Cockeysville, Maryland, USA.

Messina, V., 2014. Nutritional and health benefits of dried beans. Am. J. Clin. Nutr., 100: 437S-442S.

Mouhouche, B., F. Ruget and R. Delecolle, 1998. Effects of water stress applied at different phenological phases on yield components of dwarf bean (Phaseolus vulgaris L.). Agron., 3: 197-205.
Newton, A.C., T. Akar, J.P. Baresel, P.J. Bebeli and E. Bettencourt et al., 2010. Cereal landraces for sustainable agriculture: A review. Agron. Sustainable Dev., 30: 237-269.

Okii, D., P. Tukamuhabwa, T. Odong, A. Namayanja, J. Mukabaranga, P. Paparu and P. Gepts, 2014. Morphological diversity of tropical common bean germplasm. Afr. Crop Sc. J., 22: 59-68.

Prusinski, J. and M. Borowska, 2002. Biological potential leguminous plant and their using, P.I. Used of growth regulators in leguminous plant cultivation. Hodowla Roslini Nasiennictwo, 2: 33-38.

Ramirez-Villegas, J., A.J. Challinor, P.K. Thornton and A. Jarvis, 2013. Implications of regional improvement in global climate models for agricultural impact research. Environ. Res. Lett., Vol. 8, 10.1088/1748-9326/8/2/024018/meta

Sandoval-Avila, D.M., T.E. Michaels, S.D. Murphy and C.J. Swanton, 1994.. Effect of tillage practice and planting pattern on performance of white bean (Phaseolus vulgaris L.) in Ontario. Can. J. Plant Sci., 74: 801-805.

Schut, J.W., X. Qi and P. Stam, 1997. Association between relationship measures based on AFLP markers pedigree data and morphological traits in barley. Theor. Applied Genet., 95: 1161-1168.

Shannon, C.E. and W. Weaver, 1949. The Mathematical theory of Communication. University of Illinois Press, Urban, USA, pp: 19-107.

Stoilova, T., G. Pereira and M.D. Sousa, 2013.. Morphological characterization of a small common bean (Phaseolus vulgaris L.) collection under different environments. J. Cent. Eur. Agric., 14: $854-864$

Suzuki, K., H. Takeda, T. Tsukaguchi and Y. Egawa, 2001.. Ultrastructural study on degeneration of tapetum in anther of snap bean (Phaseolus vulgaris L.) under heat stress. Sexual Plant Reprod., 13: 293-299.

Svetleva, D., G. Pereira, J. Carlier, L. Cabrita, J. Leitao and D. Genchev, 2006. Molecular characterization of Phaseolus vulgaris L. genotypes included in Bulgarian collection by ISSR and AFLPTM analyses. Sci. Hortic., 109: 198-206.

Villa, T.C.C., N. Maxted, M. Scholten andB. Ford-Lloyd, 2005. Defining and identifying crop landraces. Plant Genet. Resour., 3: 373-384.

Wallace, R., G.P. Sanders and R.J. Ferl, 1991. Biology: The Science of Life. 3rd Edn., HarperCollins, New York, USA.,

Wood, D. and J.M. Lenne, 1997. The conservation of agrobiodiversity on-farm: questioning the emerging paradigm. Biodivers. Conserv., 6: 109-129. 